\title{
Substrate pH Affects Nutrient Availability in Fertilized Douglas Fir Bark Substrates
}

\author{
James E. Altland ${ }^{1,4}$ \\ USDA-ARS, Application Technology Research Unit, Ohio Agricultural \\ Research and Development Center, 1680 Madison Avenue, Wooster, OH 44691 \\ M. Gabriela Buamscha ${ }^{2}$ \\ USDA Forest Service, 333 SW First Avenue, Portland, OR 97208-3623 \\ Donald A. Horneck ${ }^{3}$ \\ Crop and Soil Science Department, Oregon State University, P.O. Box 105, \\ Hermiston, OR 97838
}

Additional index words. Pseudotsuga menziesii, lime, sulfur, calcium carbonate, calcium hydroxide

\begin{abstract}
An experiment was conducted to determine how $\mathrm{pH}$ and nutrient availability in douglas fir bark (DFB) substrates respond to lime and sulfur (S) rates. The treatment design was a two-by-nine factorial arrangement with two substrate types and nine pHaltering amendments. The two substrates were 100\% DFB or 75 DFB:15 sphagnum peatmoss: 10 pumice (by volume). Substrate $\mathrm{pH}$-altering amendments included elemental $\mathrm{S}$ amended at either 0.6 or $2.4 \mathrm{~kg} \cdot \mathrm{m}^{-3}$; calcium carbonate amended at $0.6,1.5$, and $5.9 \mathrm{~kg} \cdot \mathrm{m}^{-3}$; calcium hydroxide amended at $4.4,8.9$, or $23.7 \mathrm{~kg} \cdot \mathrm{m}^{-3}$; and a nonamended control. All substrates were amended by incorporating $0.9 \mathrm{~kg} \cdot \mathrm{m}^{-3}$ Micromax micronutrients before potting and topdressing $8 \mathrm{~g} /$ pot of $14 \mathrm{~N}-4.2 \mathrm{P}-11.6 \mathrm{~K}$ Osmocote controlled-release fertilizer after potting. A group of controls was also maintained for each substrate that received no fertilizer amendment (no S, lime, Micromax, or Osmocote). Four containers of each treatment were randomly selected and harvested 4 and 8 weeks after potting. Amendment with $\mathrm{S}$ decreased $\mathrm{pH}$ with increasing rate, whereas both lime types increased $\mathrm{pH}$ with increasing rate. The two substrates in general responded similarly to $S$ and lime amendments, although there were some significant effects and interactions caused by substrate type. Ammonium-N and $\mathrm{NO}_{3}-\mathrm{N}$ both decreased exponentially with increasing substrate $\mathrm{pH}$, whereas water-extractable phosphorus decreased linearly with increasing pH. Water-extractable potassium, calcium, magnesium, and sodium responded quadratically to increasing $\mathrm{pH}$ by initially decreasing and then increasing. The micronutrients boron and iron decreased with increasing $\mathrm{pH}$, whereas DTPA extractions of manganese, zinc, and copper initially increased and then decreased over the range of observed $\mathrm{pH}$.
\end{abstract}

Ornamental container crops in the Pacific Northwest are grown primarily in douglas fir [Pseudotsuga menziesii (Mirbel) Franco] bark (DFB). Similar to pine (Pinus taeda L.) bark in the southeast United States, DFB comprises the highest portion of most nursery substrates $(60 \%$ to $80 \%$ of the substrate mix; personal observation). Buamscha et al. (2007) documented that DFB alone provides sufficient micronutrients for annual vinca

Received for publication 10 July 2008. Accepted for publication 8 Sept. 2008.

${ }^{1}$ Research Horticulturist.

${ }^{2}$ Western Nursery Specialist.

${ }^{3}$ Associate Professor.

We thank Magdalena Zazirska for her skillful technical assistance.

Mention of proprietary products or a company is included for the reader's convenience and does not imply any endorsement or preferential treatment by USDA/ARS

${ }^{4}$ To whom reprint requests should be addressed; e-mail James.Altland@ars.usda.gov
[Catharanthus roseus (L.) G. Don Peppermint Cooler'] grown at low $\mathrm{pH}(4.5$ to 5.5$)$. Macronutrient and micronutrient availability may not be sufficient to support plant growth when substrate $\mathrm{pH}$ is higher. Altland (2006b) reported reduced growth of japanese maple (Acer palmatum var. atropurpureum Thunb.), hydrangea [Hydrangea macrophylla Thunb. (Ex J.A. Murr.) Ser. 'Endless Summer'], and leucothoe [Leucothoe axillaris (Lam.) D. Don] caused by a $\mathrm{pH}$-induced reduction of available nitrogen, phosphorus $(\mathrm{P})$, and micronutrients in DFB. Similar observations of reduced plant growth with high substrate $\mathrm{pH}$ have been reported for crops grown in pine bark (Wright and Hinsley, 1991).

Unfertilized DFB response to substrate $\mathrm{pH}$ has recently been documented (Altland and Buamscha, 2008). Water-extractable $\mathrm{P}$ and DTPA-extractable boron, iron, copper, and aluminum were responsive to $\mathrm{pH}$, whereas other nutrients were either nonresponsive to substrate $\mathrm{pH}$ or the observed response was deemed more likely caused by calcium competition on cation exchange sites. Lucas and Davis (1961) determined the relationship between $\mathrm{pH}$ and nutrient availability in organic soils. They concluded that the ideal $\mathrm{pH}$ range (in terms of total nutrient availability) to be $\mathrm{pH} 5.5$ to 5.8 for wood-sedge soils and $\mathrm{pH} 5.0$ for sphagnum peat soils. They further commented that this range is 1 to $1.5 \mathrm{pH}$ units lower than what was considered ideal for mineral soils. This report formed the basis for future studies as the greenhouse industry switched from mineral soils to those composed primarily of peat or bark.

Peterson (1980) documented the effect of substrate $\mathrm{pH}$ on macronutrient and micronutrient availability in a well-fertilized commercial greenhouse substrate (peatmoss, perlite, vermiculite, granite sand, and composted pine bark; ratios not given). His study agreed with Lucas and Davis (1961) in that the optimum $\mathrm{pH}$ range was 5.2 to 5.5 , which he characterized as being a whole $\mathrm{pH}$ unit

Table 1. Chemical characteristics of groundwater used for irrigation at the Oregon State University North Willamette Research and Extension Center.

\begin{tabular}{lr}
\hline $\mathrm{pH}$ & 7.0 \\
Alkalinity & $87.3 \mathrm{mg} \cdot \mathrm{L}^{-1}$ \\
Hardness & $86.8 \mathrm{mg} \cdot \mathrm{L}^{-1}$ \\
Total dissolved solids & $129.5 \mathrm{mg} \cdot \mathrm{L}^{-1}$ \\
Electrical conductivity & $0.2 \mathrm{dSm}{ }^{-1}$ \\
Sodium & $6.9 \mathrm{mg} \cdot \mathrm{L}^{-1}$ \\
Chloride & $1.5 \mathrm{mg} \cdot \mathrm{L}^{-1}$ \\
Potassium & $2.1 \mathrm{mg} \cdot \mathrm{L}^{-1}$ \\
Calcium & $19.8 \mathrm{mg} \cdot \mathrm{L}^{-1}$ \\
Magnesium & $8.9 \mathrm{mg} \cdot \mathrm{L}^{-1}$ \\
Sulfate & $12.9 \mathrm{mg} \cdot \mathrm{L}^{-1}$ \\
Iron & $0.3 \mathrm{mg} \cdot \mathrm{L}^{-1}$ \\
Manganese & $0.1 \mathrm{mg} \cdot \mathrm{L}^{-1}$ \\
Boron & $0.0 \mathrm{mg} \cdot \mathrm{L}^{-1}$ \\
Copper & $0.0 \mathrm{mg} \cdot \mathrm{L}^{-1}$ \\
Zinc & $0.1 \mathrm{mg} \cdot \mathrm{L}^{-1}$ \\
Aluminum & $0.2 \mathrm{mg} \cdot \mathrm{L}^{-1}$ \\
\hline
\end{tabular}

Table 2. Initial substrate $\mathrm{pH}$ and nutrient values of douglas fir bark (DFB) and 75 DFB:15 peat:10 pumice mix (BPP).

\begin{tabular}{lrr}
\hline Substrate parameter & & \\
$\mathrm{pH}$ & \multicolumn{1}{c}{ DFB } & \multicolumn{1}{c}{ BPP } \\
& 3.7 & 4.2 \\
\hline $\mathrm{Salt}$ & $-----\left(\mathrm{mg} \cdot \mathrm{L}^{-1}\right)$ & ------ \\
$\mathrm{NO}_{3}-\mathrm{N}$ & 438.5 & 246.5 \\
$\mathrm{NH}_{4}-\mathrm{N}$ & 0.3 & 0.2 \\
$\mathrm{P}$ & 0.8 & 0.3 \\
$\mathrm{~K}$ & 24.2 & 10.7 \\
$\mathrm{Ca}$ & 139.1 & 65.9 \\
$\mathrm{Mg}$ & 44.3 & 38.3 \\
$\mathrm{SO}$ & 28.3 & 14.0 \\
$\mathrm{Na}$ & 10.0 & 11.8 \\
$\mathrm{~B}$ & 13.6 & 15.9 \\
$\mathrm{Fe}$ & 0.6 & 0.4 \\
$\mathrm{Mn}$ & 84.3 & 69.3 \\
$\mathrm{Cu}$ & 12.9 & 10.9 \\
$\mathrm{Zn}$ & 0.5 & 0.5 \\
$\mathrm{Al}$ & 3.8 & 3.2 \\
\hline $\mathrm{All}$ & 49.7 & 28.6 \\
\hline
\end{tabular}

${ }^{\mathrm{z}}$ All units are in $\mathrm{mg} \cdot \mathrm{L}^{-1}$ with the exception of $\mathrm{pH}$. $\mathrm{P}=$ phosphorus; $\mathrm{K}=$ potassium $; \mathrm{Ca}=$ calcium; $\mathrm{Mg}$ = magnesium $; \mathrm{Na}=$ sodium $; \mathrm{B}=$ boron $; \mathrm{Fe}=$ iron; $\mathrm{Mn}=$ manganese; $\mathrm{Cu}=$ copper; $\mathrm{Zn}=$ zinc; $\mathrm{Al}=$ aluminum. 
Table 3. Substrate $\mathrm{pH}$, nitrate $\left(\mathrm{NO}_{3}-\mathrm{N}\right)$, ammonium $\left(\mathrm{NH}_{4}-\mathrm{N}\right)$, and phosphorus $(\mathrm{P})$ response to amendment with sulfur $(\mathrm{S})$, calcium carbonate $(\mathrm{CaCO})$, or calcium hydroxide $\left[\mathrm{Ca}(\mathrm{OH})_{2}\right]^{\mathrm{z}}$

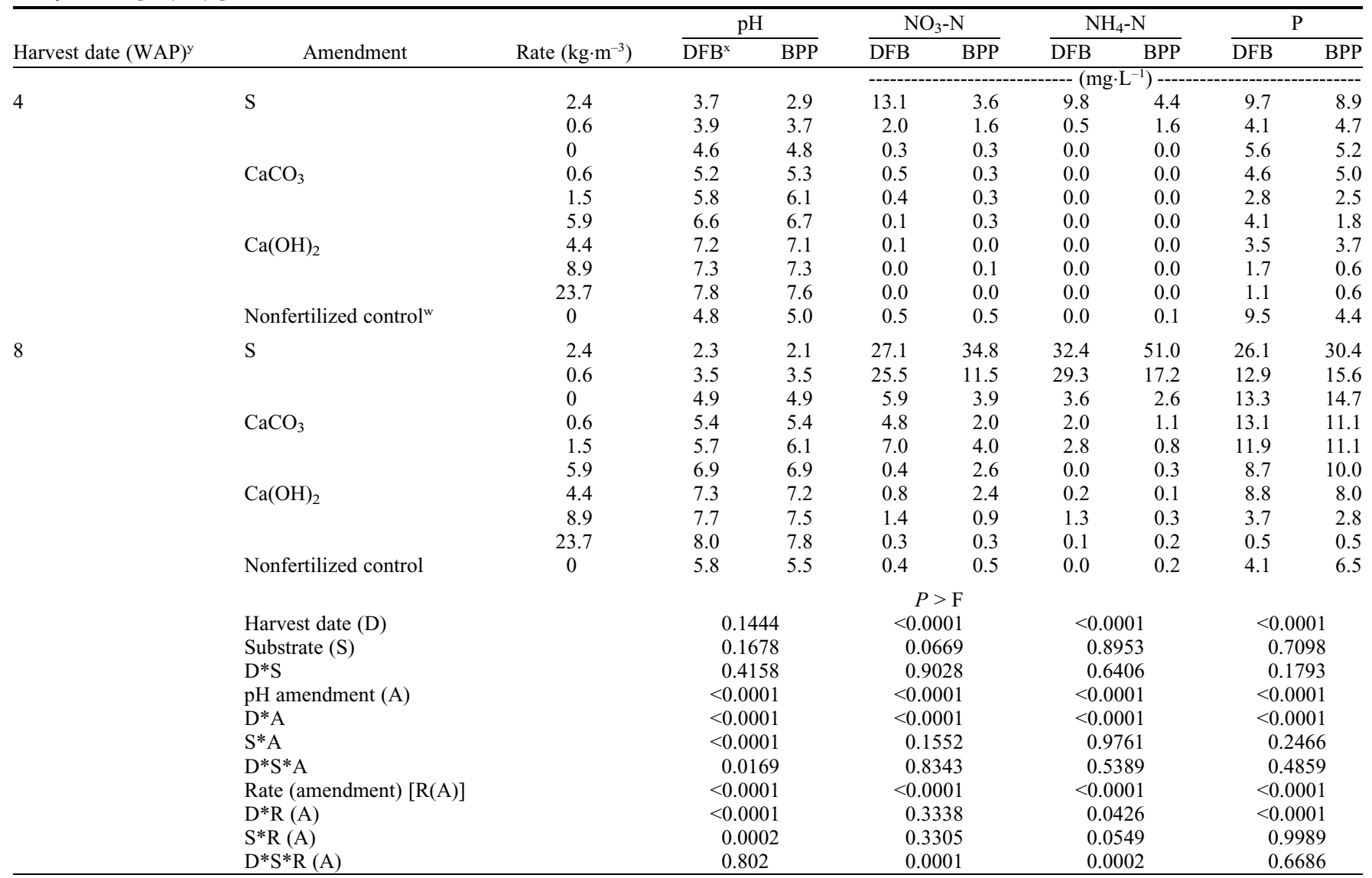

${ }^{2}$ All substrates except for controls were fertilized with Micromax micronutrient fertilizer as well as Osmocote $14 \mathrm{~N}-4.2 \mathrm{P}-11.6 \mathrm{~K}$ controlled-release fertilizer. ${ }^{\mathrm{y}} \mathrm{WAP}=$ weeks after potting, indicating when substrates were harvested for analysis.

${ }^{\mathrm{x}}$ Substrates were either $\mathrm{DFB}=100 \%$ douglas fir bark or BPP $=75$ DFB: 15 peat: 10 pumice (by volume).

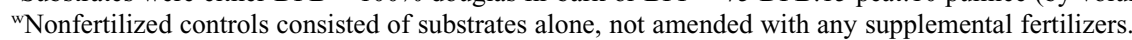

or more below what is considered optimum for mineral soils. Peterson (1980) reported decreasing availability of $\mathrm{P}$, iron (Fe), manganese $(\mathrm{Mn})$, boron $(\mathrm{B})$, zinc $(\mathrm{Zn})$, and copper $(\mathrm{Cu})$ with increasing $\mathrm{pH}$. Argo (1998) reviewed the effects of $\mathrm{pH}$ on nutrient availability in soilless substrates citing numerous sources and generally agreed with conclusions from Peterson (1980).

In view of the widespread use of DFB in the Pacific Northwest and the lack of information on its chemical properties, an experiment was initiated to document the influence of $\mathrm{pH}$ on nutrient availability in a wellfertilized substrate. The objectives were to determine the influence of elemental sulfur (S) and two lime sources on DFB pH, nutrient availability with respect to changes in substrate $\mathrm{pH}$, and if relationships between $\mathrm{pH}$ and nutrient availability in DFB alone are similar to DFB amended with peatmoss and pumice.

\section{Materials and Methods}

On 6 Feb. 2007, 20 different substrates were mixed and filled into 2.7-L containers. The treatment design was a two-by-nine factorial arrangement with two substrate types and nine $\mathrm{pH}$-altering amendments.
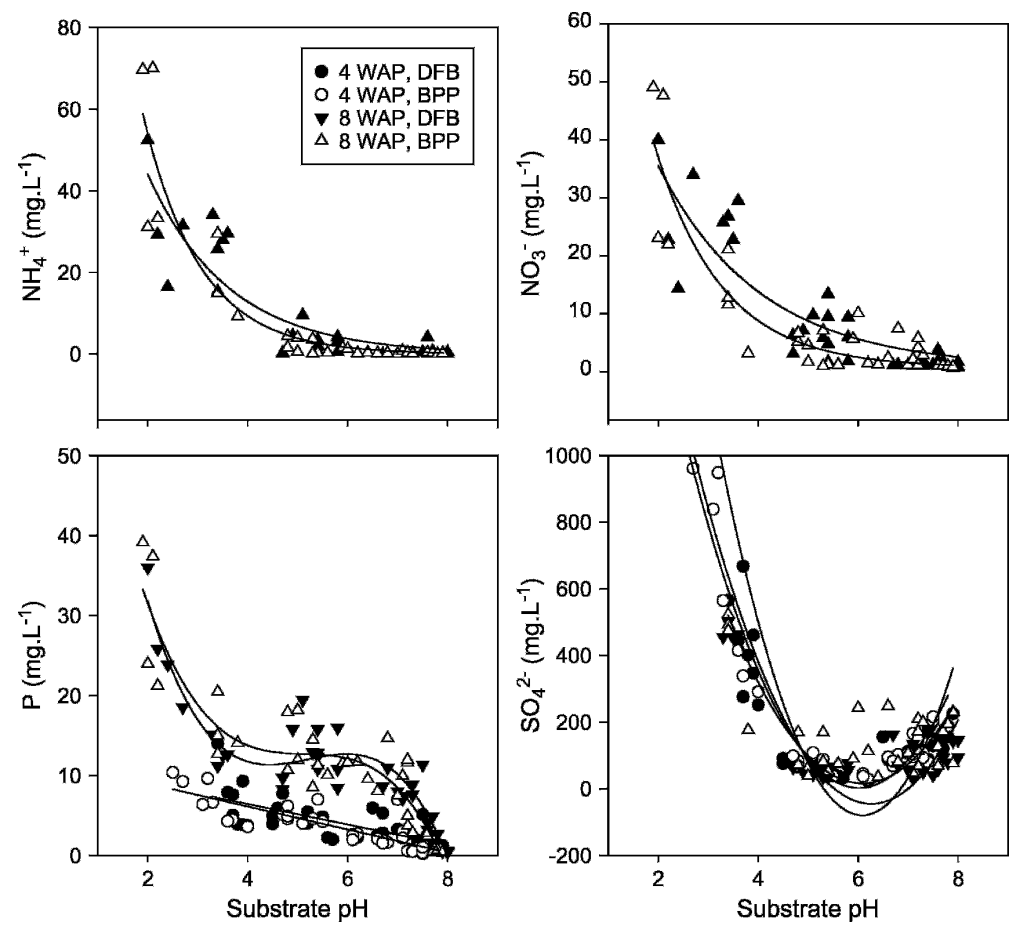

Fig. 1. Water-extractable nitrate $\left(\mathrm{NO}_{3}^{-}\right)$, ammonium $\left(\mathrm{NH}_{4}^{+}\right)$, phosphorus $(\mathrm{P})$, and sulfate $\left(\mathrm{SO}_{4}{ }^{2-}\right)$ response to substrate $\mathrm{pH}$ in a douglas fir bark (DFB) or $75 \mathrm{DFB}: 15$ peat:10 pumice (by volume) substrate. All substrates were amended with Osmocote and Micromax fertilizers and harvested either 4 or 8 weeks after potting (WAP). 

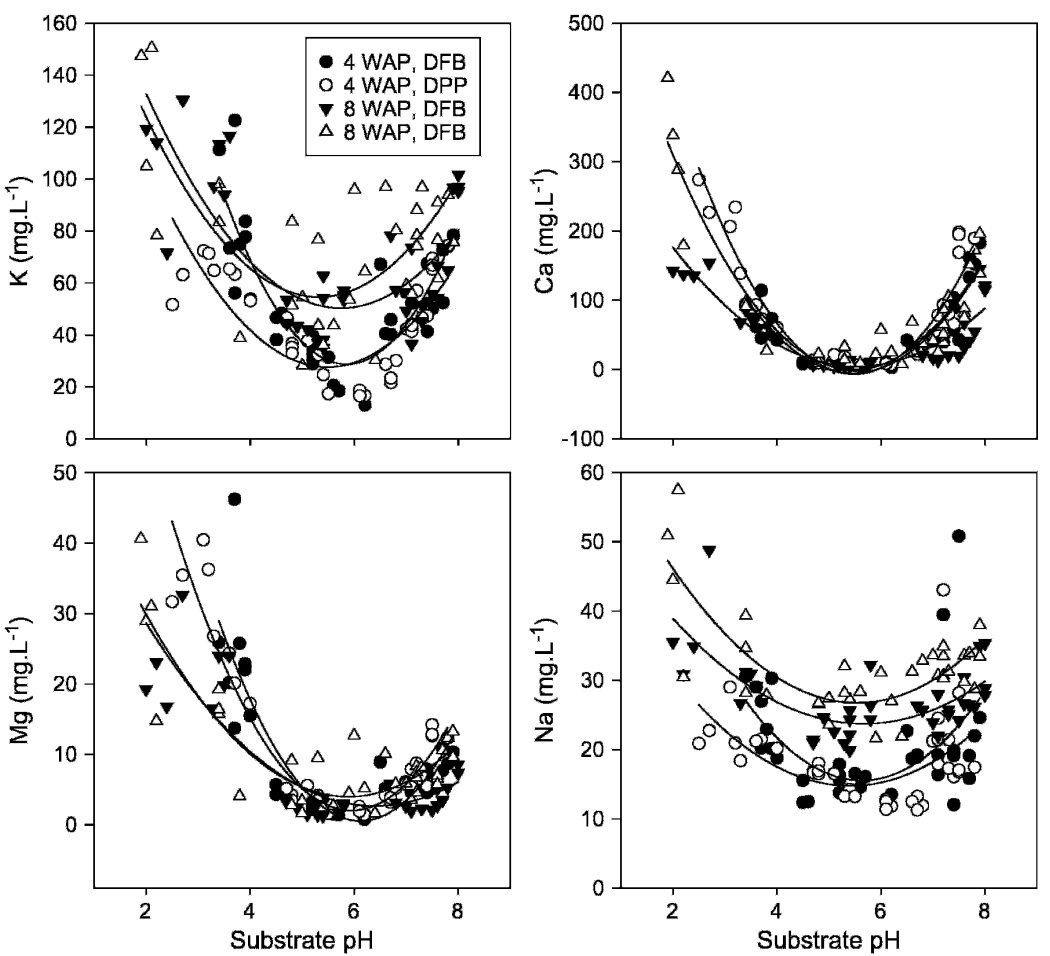

Fig. 2. Water-extractable potassium $(\mathrm{K})$, calcium $(\mathrm{Ca})$, magnesium $(\mathrm{Mg})$, and sodium $(\mathrm{Na})$ response to substrate $\mathrm{pH}$ in a douglas fir bark (DFB) or 75 DFB:15 peat:10 pumice (by volume) substrate. All substrates were amended with Osmocote and Micromax fertilizers and harvested either 4 or 8 weeks after potting (WAP).
The two substrate types were $100 \%$ DFB or 75 DFB:15 sphagnum peatmoss:10 pumice (by volume; hereafter referred to as BPP). Substrate $\mathrm{pH}$-altering amendments included elemental S (Yellowstone Sulfur; MT Sulfur Co., Billings, MT) amended at either 0.6 or $2.4 \mathrm{~kg} \cdot \mathrm{m}^{-3}$; calcium carbonate $\left(\mathrm{CaCO}_{3}\right.$; Imperial Limestone; J.A. Jack and Sons Inc., Seattle, WA) amended at 0.6, 1.5, and 5.9 $\mathrm{kg} \cdot \mathrm{m}^{-3}$; hydrated lime [calcium hydroxide, $\left.\mathrm{Ca}(\mathrm{OH})_{2}\right]$; Kemilime; Ash Grove Cement Co., Portland, OR) amended at 4.4, 8.9, or $23.7 \mathrm{~kg} \cdot \mathrm{m}^{-3}$; and a nonamended control. All substrates were further amended by incorporating $0.9 \mathrm{~kg} \cdot \mathrm{m}^{-3}$ Micromax micronutrients (The Scotts Co., Marysville, $\mathrm{OH}$ ) before potting and topdressing $8 \mathrm{~g} /$ pot of $14 \mathrm{~N}-4.2 \mathrm{P}$ 11.6K (Osmocote 14-14-14; The Scotts Co.) after potting. A group of controls were also maintained for each substrate that received no fertilizer amendment (no S, lime, Micromax, or Osmocote). Rates of lime and S were selected to provide substrates with a spectrum of low to high $\mathrm{pH}$ and were based on previous research by the authors (unpublished data). Calcium carbonate $[97 \%$ $\mathrm{CaCO}_{3}, 2 \% \mathrm{MgCO}_{3}, 97$ calcium carbonate equivalency $(\mathrm{CCE})]$ was processed such that $100 \%$ and $80 \%$ passed through 40 and 100 mesh, respectively. Hydrated lime [94\% $\left.\mathrm{Ca}(\mathrm{OH})_{2}, 126 \mathrm{CCE}\right]$ was processed such that

Table 4. Potassium $(\mathrm{K})$, calcium $(\mathrm{Ca})$, magnesium $(\mathrm{Mg})$, and sodium $(\mathrm{Na})$ response to amendment with sulfur $(\mathrm{S})$, calcium carbonate $\left(\mathrm{CaCO}_{3}\right)$, or calcium hydroxide $\left[\mathrm{Ca}(\mathrm{OH})_{2}\right]^{2}$

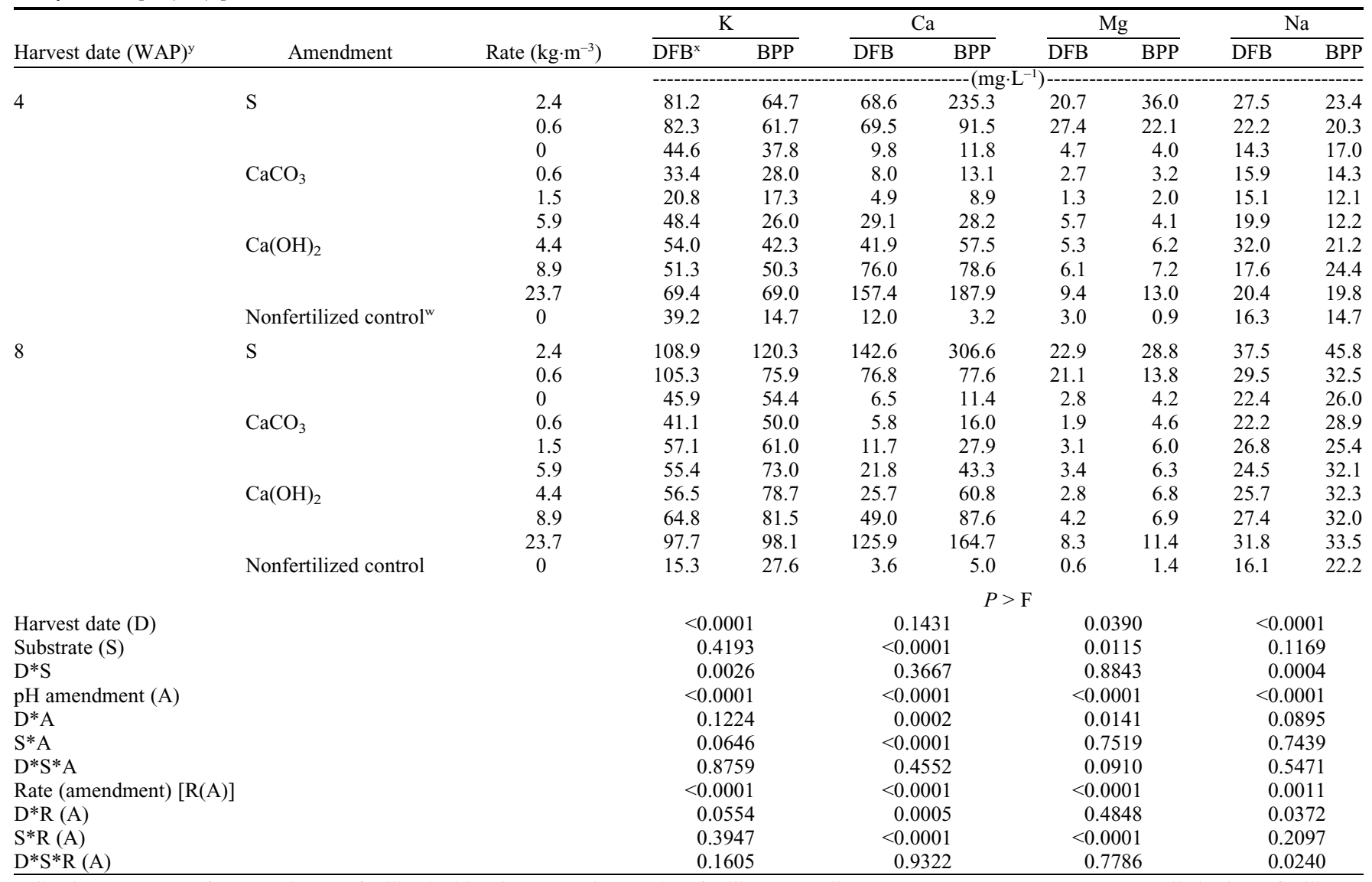

${ }^{\mathrm{z}}$ All substrates except for controls were fertilized with Micromax micronutrient fertilizer, as well as Osmocote $14 \mathrm{~N}-4.2 \mathrm{P}-11.6 \mathrm{~K}$ controlled-release fertilizer.

${ }^{\mathrm{y}} \mathrm{WAP}=$ weeks after potting, indicating when substrates were harvested for analysis.

${ }^{\mathrm{x}}$ Substrates were either DFB $=100 \%$ douglas fir bark or BPP $=75$ DFB: 15 peat: 10 pumice (by volume)

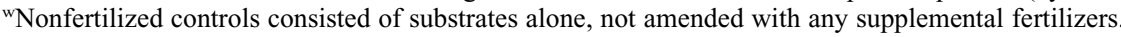


$100 \%$ and $99 \%$ passed through 40 and 100 mesh, respectively. Sulfur $(80 \%)$ was processed as a fine dust (particle size not provided). Bark was ground with a hammer-mill, passed through a 2.2-cm screen, and aged for $\approx 6$ months (Marr Bros. Co., Monmouth, OR). Eight No. 1 containers $(2.8$ L) were filled with each treatment and maintained in a hoop house in Aurora, OR. Temperatures within the hoophouse were maintained above $15{ }^{\circ} \mathrm{C}$. Containers received overhead irrigation with groundwater at a rate of $1.2 \mathrm{~cm} \cdot \mathrm{d}^{-1}$. Chemical properties of irrigation water used for the experiment were determined (Table 1). Before amendment with fertilizers, two samples from each substrate were collected to determine initial nutrient levels (Table 2). Four containers of each treatment were randomly selected and harvested 4 and 8 weeks after potting (WAP). Substrates were harvested by first scraping the top $1.5 \mathrm{~cm}$ of substrate away and thereby removing all controlled-released fertilizer (CRF) prills. The remaining substrate was placed into a plastic bag, rechecked to ensure no CRF prills remained, and then delivered to the laboratory. Bark samples were analyzed for $\mathrm{pH}$, ammonium $\left(\mathrm{NH}_{4}-\mathrm{N}\right)$, nitrate $\left(\mathrm{NO}_{3}-\mathrm{N}\right), \mathrm{P}$, potassium $(\mathrm{K})$, calcium $(\mathrm{Ca})$, magnesium $(\mathrm{Mg})$, and sulfate $\left(\mathrm{SO}_{4}{ }^{2-}\right)$ using the saturated media extract (SME) method with deionized water as the extractant (Gavlak et al., 2003; Warncke, 1998). Boron, Fe, Mn, Cu, Zn, and aluminum (Al) were analyzed using a SME with diethylenetriaminepentaacetic acid (DTPA) as the extractant (Warncke, 1998). Following Gavlak et al. (2003), separate subsamples of each replicate were soaked in either water or $0.005 \mathrm{M}$ DTPA for $24 \mathrm{~h}$. Ammonium and $\mathrm{NO}_{3}-\mathrm{N}$ in extracted solutions were analyzed colorimetrically using a Lachat Quick Chem 8000 (Lachat Instruments, Milwaukee, WI). All other elements were analyzed with inductively coupled plasma-emission spectrometry (Thermo Jarrel Ash, Offenbach, Germany).

Data were analyzed with analysis of variance to determine significant main effects. Nonlinear regression was used to determine the most appropriate model for $\mathrm{pH}$ response to lime rate as well as nutrient availability response to substrate $\mathrm{pH}$. Procedures described by Schabenberger and Pierce (2002) were used for nonlinear model selection and comparison. Linear, curvilinear, and piecewise regression models were compared using the lack of fit test to determine the most appropriate model for regressing substrate $\mathrm{pH}$ on each extractable nutrient. All statistical analyses were conducted with SAS 9.1 (SAS Institute, Cary, NC), although figures were constructed with SigmaPlot 10.0 (Systat Software, Inc., San Jose, CA).

\section{Results and Discussion}

Sulfur amendment reduced $\mathrm{pH}$ with increasing $\mathrm{S}$ rate, whereas lime additions [both $\mathrm{CaCO}_{3}$ and $\mathrm{Ca}(\mathrm{OH})_{2}$ ] increased $\mathrm{pH}$ (Table 3). Substrate $\mathrm{pH}$ declined from 4 to 8 WAP with $\mathrm{S}$ additions and increased

Table 5. Salt, sulfate $\left(\mathrm{SO}_{4}{ }^{2-}\right)$, and aluminum ( $\left.\mathrm{Al}\right)$ response to amendment with sulfur ( $\left.\mathrm{S}\right)$, calcium carbonate $\left(\mathrm{CaCO}_{3}\right)$, or calcium hydroxide $\left[\mathrm{Ca}(\mathrm{OH})_{2}\right]^{\mathrm{z}}$

\begin{tabular}{|c|c|c|c|c|c|c|}
\hline \multirow{2}{*}{ Harvest date (WAP) ${ }^{\mathrm{y}}$} & \multirow[b]{2}{*}{ Amendment } & \multirow[b]{2}{*}{ Rate $\left(\mathrm{kg} \cdot \mathrm{m}^{-3}\right)$} & \multicolumn{2}{|c|}{$\mathrm{SO}_{4}{ }^{2-}$} & \multicolumn{2}{|c|}{$\mathrm{Al}$} \\
\hline & & & $\overline{D F B}^{x}$ & $\mathrm{BPP}$ & $\overline{\mathrm{DFB}}$ & BPP \\
\hline \multirow[t]{10}{*}{4} & 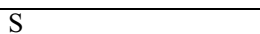 & 2.4 & 436.8 & 952.8 & 13.4 & 41.8 \\
\hline & & 0.6 & 417.0 & 402.4 & 10.0 & 6.3 \\
\hline & & 0 & 82.4 & 78.8 & 8.9 & 4.6 \\
\hline & $\mathrm{CaCO}_{3}$ & 0.6 & 62.2 & 68.0 & 4.9 & 3.5 \\
\hline & & 1.5 & 34.0 & 37.4 & 2.8 & 1.9 \\
\hline & & 5.9 & 100.8 & 87.5 & 0.7 & 1.4 \\
\hline & $\mathrm{Ca}(\mathrm{OH})_{2}$ & 4.4 & 122.2 & 117.8 & 0.6 & 1.1 \\
\hline & & 8.9 & 139.9 & 107.3 & 1.4 & 0.5 \\
\hline & & 23.7 & 164.5 & 202.2 & 1.7 & 1.6 \\
\hline & Nonfertilized control ${ }^{\mathrm{w}}$ & 0 & 10.3 & 8.1 & 21.8 & 5.9 \\
\hline \multirow[t]{11}{*}{8} & $\mathrm{~S}$ & 2.4 & 1343.7 & 2273.8 & 82.8 & 151.0 \\
\hline & & 0.6 & 468.7 & 416.5 & 7.1 & 7.3 \\
\hline & & 0 & 57.1 & 86.2 & 3.2 & 5.0 \\
\hline & $\mathrm{CaCO}_{3}$ & 0.6 & 37.9 & 94.5 & 1.8 & 5.3 \\
\hline & & 1.5 & 69.2 & 120.3 & 2.2 & 1.5 \\
\hline & & 5.9 & 81.1 & 121.0 & 0.7 & 0.8 \\
\hline & $\mathrm{Ca}(\mathrm{OH})_{2}$ & 4.4 & 69.5 & 141.0 & 0.5 & 0.7 \\
\hline & & 8.9 & 95.5 & 143.2 & 1.3 & 0.7 \\
\hline & & 23.7 & 132.9 & 168.4 & 1.0 & 0.6 \\
\hline & Nonfertilized control & 0 & 8.3 & 12.9 & 5.1 & 6.1 \\
\hline & & & \multicolumn{4}{|c|}{$P>\mathrm{F}$} \\
\hline \multicolumn{3}{|l|}{ Harvest date (D) } & \multirow{2}{*}{\multicolumn{2}{|c|}{0.0024}} & \multicolumn{2}{|c|}{0.0183} \\
\hline \multicolumn{3}{|l|}{ Substrate (S) } & & & \multicolumn{2}{|c|}{0.0136} \\
\hline \multicolumn{3}{|l|}{$\mathrm{D} * \mathrm{~S}$} & \multicolumn{2}{|c|}{$\begin{array}{r}<0.0001 \\
0.0006\end{array}$} & \multicolumn{2}{|c|}{0.3000} \\
\hline \multicolumn{3}{|l|}{ pH amendment (A) } & \multicolumn{2}{|c|}{$<0.0001$} & \multicolumn{2}{|c|}{$<0.0001$} \\
\hline \multicolumn{3}{|l|}{ D*A } & \multicolumn{2}{|c|}{$<0.0001$} & \multicolumn{2}{|c|}{0.0019} \\
\hline \multicolumn{3}{|l|}{$\mathrm{S}^{*} \mathrm{~A}$} & \multicolumn{2}{|c|}{$<0.0001$} & \multirow{2}{*}{\multicolumn{2}{|c|}{$<0.0001$}} \\
\hline \multicolumn{3}{|l|}{$\mathrm{D} * \mathrm{~S} * \mathrm{~A}$} & \multicolumn{2}{|c|}{$<0.0001$} & \multirow{2}{*}{\multicolumn{2}{|c|}{$\begin{array}{r}0.0683 \\
<0.0001\end{array}$}} \\
\hline Rate (amendment) [R( & & & \multicolumn{2}{|c|}{$<0.0001$} & & \\
\hline $\mathrm{D} * \mathrm{R}(\mathrm{A})$ & & & $<0$. & 001 & & 096 \\
\hline $\mathrm{S} * \mathrm{R}(\mathrm{A})$ & & & $<0$. & 001 & & 004 \\
\hline $\mathrm{D} * \mathrm{~S} * \mathrm{R}(\mathrm{A})$ & & & & 204 & & 413 \\
\hline
\end{tabular}

${ }^{2}$ All substrates except for controls were fertilized with Micromax micronutrient fertilizer as well as Osmocote $14 \mathrm{~N}-4.2 \mathrm{P}-11.6 \mathrm{~K}$ controlled-release fertilizer.

${ }^{\mathrm{y}} \mathrm{WAP}=$ weeks after potting, indicating when substrates were harvested for analysis.

${ }^{\mathrm{x}}$ Substrates were either DFB $=100 \%$ douglas fir bark or BPP $=75$ DFB: 15 peat: 10 pumice (by volume).

"Nonfertilized controls consisted of substrates alone, not amended with any supplemental fertilizers.

slightly with lime additions. Substrate response to $\mathrm{S}$ is biological, because bacteria from the genus Thiobacillus converts $\mathrm{S}$ to $\mathrm{SO}_{4}{ }^{2-}$ and concomitantly release $\mathrm{H}^{+}$ions. This biological reaction generally takes place over several weeks or months pending adequate moisture and temperature (greater than $10^{\circ} \mathrm{C}$ ). Substrate reaction to lime is chemical in nature and dependent on lime acid neutralizing capacity, lime type, and lime particle size (Fisher et al., 2006); thus, reaction to pulverized lime (like used in this study) can be immediate. Substrate type had no effect on substrate $\mathrm{pH}(P=0.1678)$, although there were several significant interactions with other main effects. Within a treatment, there were generally minor differences in $\mathrm{pH}$ response between the two substrate types, suggesting that both substrates responded similarly to $\mathrm{S}$ and lime.

Nitrate- $\mathrm{N}$ and $\mathrm{NH}_{4}-\mathrm{N}$ both responded to the three-way interaction of date, substrate type, and rate of $\mathrm{pH}$ amendment (Table 3 ). Ammonium and $\mathrm{NO}_{3}-\mathrm{N}$ levels were relatively low across all treatments at 4 WAP but higher by 8 WAP. Nutrient release from the CRF is likely responsible for changes in $\mathrm{N}$ levels over time. Ammonium-N and $\mathrm{NO}_{3}-\mathrm{N}$ both decreased exponentially with increasing substrate $\mathrm{pH}$ (Fig. 1). The response to $\mathrm{pH}$ for both nitrogen $(\mathrm{N})$ forms was more evident 8 WAP when overall $\mathrm{N}$ levels were higher. Ammonium-N response to $\mathrm{pH}$ was likely the result of $\mathrm{pH}$-dependent nitrification. Ogden et al. (1987) attributed the increased nitrification response to greater activity of nitrifying bacteria in higher $\mathrm{pH}$ substrates. Niemiera and Wright (1986) demonstrated that nitrifying bacteria were largely responsible for loss of ammonium in container substrates with lime-induced high $\mathrm{pH}$. Nitrate-N response may be linked to anion exchange capacity (AEC). Anion exchange capacity increases with decreasing $\mathrm{pH}$ as a result of protonation of carboxyl and hydroxyl groups. This has been demonstrated in two organic arboreal soils comprised primarily of redwood [Sequoia sempervirens (D. Don) Endl.] leaves and bark, in which $\mathrm{AEC}$ at $\mathrm{pH} 4$ was 1.2 to two times more than at pH 7 (Enloe et al., 2006). Increased AEC at lower $\mathrm{pH}$ in our study may have allowed more readily extractable $\mathrm{NO}_{3}$ to be retained by the substrate. This may also allow for greater $\mathrm{N}$ availability to plants and less $\mathrm{NO}_{3}-\mathrm{N}$ leaching in production situations.

Neither substrate type nor any of its interactions affected water-extractable $P$ (Table 3). Previous research has shown that 
Table 6. Boron $(\mathrm{B})$, iron $(\mathrm{Fe})$, manganese $(\mathrm{Mn})$, copper $(\mathrm{Cu})$, and zinc $(\mathrm{Zn})$ response to amendment with sulfur $(\mathrm{S})$, calcium carbonate $(\mathrm{CaCO})_{3}$, or calcium hydroxide $\left[\mathrm{Ca}(\mathrm{OH})_{2}\right]^{\mathrm{z}}$

\begin{tabular}{|c|c|c|c|c|c|c|c|c|c|c|c|c|}
\hline \multirow{2}{*}{ Harvest date (WAP) ${ }^{\mathrm{y}}$} & \multirow[b]{2}{*}{ Amendment } & \multirow[b]{2}{*}{ Rate $\left(\mathrm{kg} \cdot \mathrm{m}^{-3}\right)$} & \multicolumn{2}{|c|}{$\mathrm{B}$} & \multicolumn{2}{|c|}{$\mathrm{Fe}$} & \multicolumn{2}{|c|}{$\mathrm{Mn}$} & \multicolumn{2}{|c|}{$\mathrm{Cu}$} & \multicolumn{2}{|c|}{$\mathrm{Zn}$} \\
\hline & & & $\overline{\mathrm{DFB}^{\mathrm{x}}}$ & $\mathrm{BPP}$ & $\overline{\mathrm{DFB}}$ & BPP & $\overline{\mathrm{DFB}}$ & $\mathrm{BPP}$ & $\overline{\mathrm{DFB}}$ & $\mathrm{BPP}$ & $\overline{\mathrm{DFB}}$ & $\mathrm{BPP}$ \\
\hline \multirow[t]{7}{*}{4} & $\mathrm{~S}$ & 2.4 & 0.4 & 0.6 & 103.1 & 109.9 & $\begin{aligned}-(\mathrm{mg} \cdot 1 \\
9.4\end{aligned}$ & $\begin{array}{l}-1)---- \\
28.5\end{array}$ & 4.1 & 3.7 & 6.6 & 10.5 \\
\hline & & 0.6 & 0.8 & 0.5 & 121.4 & 90.0 & 20.5 & 21.5 & 6.5 & 4.3 & 8.5 & 9.3 \\
\hline & $\mathrm{CaCO}_{3}$ & 0.6 & 0.4 & 0.3 & 74.4 & 84.4 & 16.8 & 12.8 & 4.8 & 7.2 & 9.5 & 11.2 \\
\hline & & 1.5 & 0.2 & 0.3 & 60.0 & 59.7 & 16.3 & 23.3 & 3.7 & 6.0 & 6.7 & 9.6 \\
\hline & & 5.9 & 0.1 & 0.1 & 25.5 & 26.0 & 26.5 & 32.4 & 3.1 & 4.7 & 7.9 & 10.1 \\
\hline & & 23.7 & 0.1 & 0.1 & 2.4 & 2.4 & 20.8 & 23.1 & 2.3 & 3.0 & 6.4 & 6.9 \\
\hline & Nonfertilized controlw & 0 & 0.2 & 0.2 & 43.9 & 39.4 & 10.8 & 10.6 & 0.3 & 0.3 & 2.2 & 2.0 \\
\hline \multirow[t]{6}{*}{8} & $\mathrm{~S}$ & 2.4 & 0.4 & 0.4 & 113.8 & 90.7 & 8.1 & 9.6 & 4.6 & 4.5 & 3.3 & 3.8 \\
\hline & & 0.6 & 0.5 & 0.3 & 115.5 & 91.0 & 16.9 & 6.0 & 6.0 & 4.8 & 6.8 & 4.9 \\
\hline & & 0 & 0.2 & 0.3 & 85.3 & 81.1 & 12.8 & 15.2 & 5.6 & 6.0 & 8.0 & 9.5 \\
\hline & $\mathrm{CaCO}_{3}$ & 0.6 & 0.2 & 0.3 & 85.0 & 82.2 & 16.3 & 17.2 & 6.1 & 7.6 & 9.7 & 11.3 \\
\hline & Nonfertilized control & 0 & 0.2 & 0.2 & 43.7 & 38.5 & 11.3 & 12.1 & 0.3 & 0.3 & 2.3 & 2.0 \\
\hline & & & \multicolumn{10}{|c|}{$P>\mathrm{F}$} \\
\hline Harvest date (D) & & & \multicolumn{2}{|c|}{$<0.0001$} & \multicolumn{2}{|c|}{0.7396} & \multicolumn{2}{|c|}{0.2389} & \multicolumn{2}{|c|}{$<0.0001$} & \multicolumn{2}{|c|}{0.6434} \\
\hline Substrate $(\mathrm{S})$ & & & \multicolumn{2}{|c|}{0.4469} & \multicolumn{2}{|c|}{0.0016} & \multicolumn{2}{|c|}{0.9579} & \multicolumn{2}{|c|}{$<0.0001$} & \multicolumn{2}{|c|}{$<0.0001$} \\
\hline$D * S$ & & & & & \multirow{2}{*}{\multicolumn{2}{|c|}{$\begin{array}{r}0.0032 \\
<0.0001\end{array}$}} & \multicolumn{2}{|c|}{$<0.0001$} & \multicolumn{2}{|c|}{0.7308} & \multicolumn{2}{|c|}{0.1782} \\
\hline $\mathrm{pH}$ amendment (A) & & & \multicolumn{2}{|c|}{$<0.0001$} & & & $<0$. & & & & $<0$. & \\
\hline $\mathrm{D} * \mathrm{~A}$ & & & $<0$. & & 0.0 & & $<0$. & & & & $<0$. & \\
\hline $\mathrm{S}^{*} \mathrm{~A}$ & & & & & $<0.0$ & & $<0$. & & & & & \\
\hline $\mathrm{D} * \mathrm{~S} * \mathrm{~A}$ & & & & & 0.0 & & $<0$. & & & & & 137 \\
\hline Rate (amendment [R(A)] & & & $<0$. & & $<0.0$ & & $<0$. & & & & $<0$. & \\
\hline $\mathrm{D} * \mathrm{R}(\mathrm{A})$ & & & & & 0.8 & & & & & & $<0$. & \\
\hline $\mathrm{S} * \mathrm{R}(\mathrm{A})$ & & & $<0$. & & 0.0 & & & & & & & \\
\hline$D * S * R(A)$ & & & & & & & & & & & & \\
\hline
\end{tabular}

${ }^{\mathrm{z}}$ All substrates except for controls were fertilized with Micromax micronutrient fertilizer as well as Osmocote $14 \mathrm{~N}-4.2 \mathrm{P}-11.6 \mathrm{~K}$ controlled-release fertilizer.

${ }^{\mathrm{y}} \mathrm{WAP}=$ weeks after potting, indicating when substrates were harvested for analysis.

${ }^{\mathrm{x}}$ Substrates were either DFB $=100 \%$ douglas fir bark or BPP $=75$ DFB: 15 peat: 10 pumice (by volume)

wNonfertilized controls consisted of substrates alone, not amended with any supplemental fertilizers.

$\mathrm{P}$ is $\mathrm{pH}$-dependent in nonamended DFB (Altland and Buamscha, 2008). Water-extractable $\mathrm{P}$ decreased with increasing $\mathrm{pH}$ at 4 and 8 WAP (Fig. 1) and thus is pH-dependent even with higher levels of $\mathrm{P}$ made available by CRF. Favaretto et al. (2006) showed that applications of $\mathrm{Ca}$ in the form of gypsum $\left(\mathrm{CaSO}_{4}\right)$ reduced $\mathrm{P}$ concentration in mineral soil by converting the readily desorbable $\mathrm{P}$ to less soluble $\mathrm{Ca}-\mathrm{P}$ compounds. This phenomena was not observed in our study, because $P$ increased with decreasing $\mathrm{pH}$ concomitantly with sharply increasing levels of soluble $\mathrm{Ca}$ (Fig. 2).

Potassium, calcium, magnesium, and sodium. Water-extractable $\mathrm{K}, \mathrm{Ca}, \mathrm{Mg}$, and sodium $(\mathrm{Na})$ each responded differently to main effects of substrate type, amendment, and amendment rate (Table 4). All responded quadratically to increasing $\mathrm{pH}$ (Fig. 2). The $\mathrm{pH}$ resulting in minimal nutrient availability was calculated for each nutrient by setting the first derivative of the quadratic function to zero and solving for $\mathrm{pH}$. Substrate $\mathrm{pH}$ at which extracted levels were minimal for K, $\mathrm{Ca}$, and $\mathrm{Na}$ was 5.5 , whereas it was 6.2 for $\mathrm{Mg}$. In previous research, water-extractable $\mathrm{K}, \mathrm{Ca}$, and $\mathrm{Mg}$ increased with increasing $\mathrm{pH}$ in nonamended DFB, whereas $\mathrm{Na}$ did not respond to $\mathrm{pH}$ (Altland and Buamscha, 2008). Increased $\mathrm{Ca}$ availability was attrib- uted to increased rate and solubility of $\mathrm{Ca}(\mathrm{OH})_{2}$, and a similar rationale is appropriate here. Increased $\mathrm{K}$ and $\mathrm{Mg}$ availability was attributed to dislodging of the cations from cation exchange sites with increasing levels of soluble $\mathrm{Ca}$. The same explanation can be applied for $\mathrm{K}, \mathrm{Mg}$, and $\mathrm{Na}$ in this study. Increased water-extractable $\mathrm{K}, \mathrm{Ca}, \mathrm{Mg}$, and $\mathrm{Na}$ from $\mathrm{pH}$-lowering $\mathrm{S}$ applications may be caused by elevated $\mathrm{H}^{+}$concentrations. Hydrogen ions have large atomic radii and thus would displace cations with smaller radii (i.e., $\mathrm{K}, \mathrm{Ca}, \mathrm{Mg}$, and $\mathrm{Na}$ ) on cation exchange sites, causing their availability to increase with decreasing $\mathrm{pH}$. Berghage et al. (1987) similarly reported that $\mathrm{Ca}$ decreased from 700 to $800 \mathrm{mg} \cdot \mathrm{L}^{-1}$ when $\mathrm{pH}$ was just below 4 to under $300 \mathrm{mg} \cdot \mathrm{L}^{-1}$ at $\mathrm{pH}$ 5.5. They (Berghage et al., 1987) also reported a similar trend with $\mathrm{Mg}$ and to a lesser extent $\mathrm{K}$ (without data).

Analysis of variance shows that all main effects influenced substrate $\mathrm{SO}_{4}{ }^{2-}$ levels (Table 5). Addition of lime and subsequent increase in $\mathrm{pH}$ caused an increase in waterextractable $\mathrm{SO}_{4}{ }^{2-}$ (Fig. 1). This is similar to what was observed with the nonamended DFB response to lime (Altland and Buamscha, 2008). With increasing $\mathrm{pH}$ there is a logarithmic increase in $\mathrm{OH}^{-}$concentration. Similar to cation competition described for K,
$\mathrm{Mg}$, and $\mathrm{Na}$, elevated levels of $\mathrm{OH}^{-}$may have displaced sulfate ions on anion exchange sites causing an increase in water-extractable sulfate levels. Bennett and Peterson (1989) reported a slight increase in sulfate from $\mathrm{pH}$ 3.7 to 4.7 in sphagnum peat amended with increasing rates of $\mathrm{Ca}(\mathrm{OH})_{2}$ but declining sulfate levels with $\mathrm{pH}$ increasing from 4.7 to 7.0. Differences in response between the two studies may be caused by the different substrates or extraction procedures used. Handreck (1986) states that $6 \mathrm{mg} \cdot \mathrm{L}^{-1}$ waterextractable $\mathrm{SO}_{4}{ }^{2-}$ is sufficient for any crop. By this standard, even nonfertilized controls would contain sufficient extractable $\mathrm{SO}_{4}{ }^{2-}$ for plant growth. Amendment with $\mathrm{S}$ resulted in $\mathrm{SO}_{4}{ }^{2-}$ levels greater than 10 to 100 times more than needed for crop growth. Elevated $\mathrm{SO}_{4}{ }^{2-}$ levels in $\mathrm{S}$-amended containers are more likely the result of $\mathrm{S}$ and not related to low $\mathrm{pH}$. Across all lime and $\mathrm{S}$ treatments, water-extractable $\mathrm{SO}_{4}{ }^{2-}$ levels were higher in fertilized containers compared with nonfertilized controls (Table 5). The N-P-K fertilizer in this experiment used potassium sulfate as the sole $\mathrm{K}$ source, whereas the micronutrient fertilizer was comprised partly of copper sulfate, manganese sulfate, ferrous sulfate, and zinc sulfate. Thus, DFB alone likely has sufficient $\mathrm{SO}_{4}{ }^{2-}$ to support plant growth, whereas addition of typical sulfated 

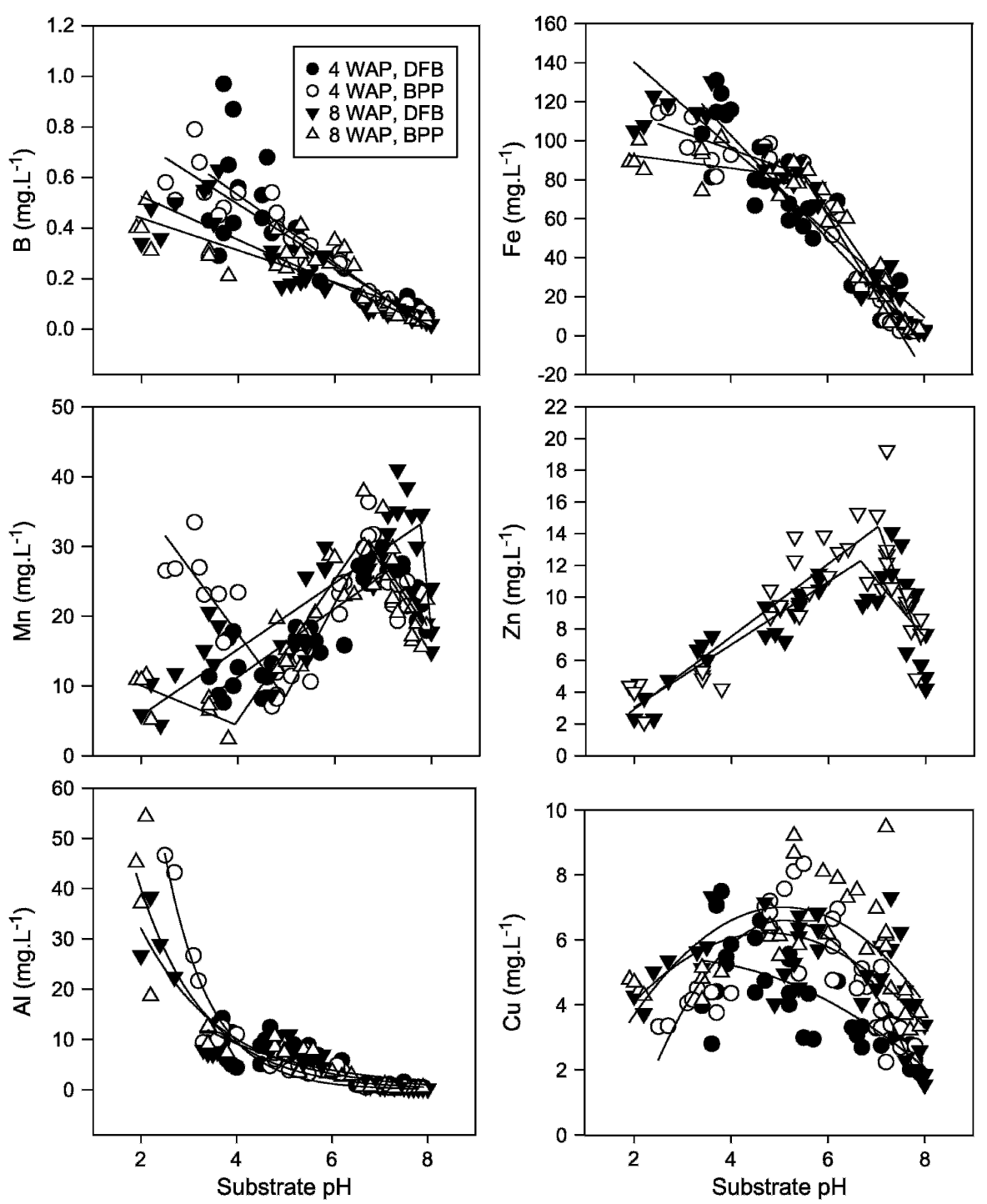

Fig. 3. DTPA-extractable boron (B), iron (Fe), manganese $(\mathrm{Mn})$, zinc $(\mathrm{Zn})$, copper $(\mathrm{Cu})$, and aluminum (A1) response to substrate $\mathrm{pH}$ in a douglas fir bark (DFB) or 75 DFB:15 peat:10 pumice (by volume) substrate. All substrates were amended with Osmocote and Micromax fertilizers and harvested either 4 or 8 weeks after potting (WAP).

$\mathrm{N}-\mathrm{P}-\mathrm{K}$ and micronutrient fertilizers certainly provide sufficient $\mathrm{SO}_{4}{ }^{2-}$.

Micronutrients. The main effect of substrate type did not affect DTPA-extractable B $(P=0.4469$; Table 6); however, there were several significant interactions between substrate type and other main effects. DTPA-extractable B decreased linearly with increasing $\mathrm{pH}$ (Fig. 3). DTPA-extractable B in nonfertilized DFB (Altland and Buamscha, 2008) was similar to B levels in fertilized DFB across the range of observed $\mathrm{pH}$. The micronutrient fertilizer package used in this study contains $0.1 \% \mathrm{~B}$ in the form of sodium borate. Within the substrate, sodium borate probably changes to boric acid $\left[\mathrm{B}(\mathrm{OH})_{4}{ }^{-}\right]$, which is very water-soluble $(\approx 57,000$ $\left.\mathrm{mg} \cdot \mathrm{L}^{-1}\right)$. Lack of discernible differences in DTPA-extractable B between DFB amended with micronutrient fertilizers and those not amended can be attributed to either rapid leaching of water-soluble boric acid or the B fraction of the fertilizer is minor compared with the fraction provided by DFB and other substrate components. Available B in container plants can also originate from irrigation water (Ogden et al., 1987). Boron levels in irrigation water in this experiment were negligible (Table 1) and, across container nurseries in Oregon, were found to be very low (0 to $0.07 \mathrm{mg} \cdot \mathrm{L}^{-1}$ ) (Altland, 2006a). Plant-available B is governed by the amount of B in solution (Goldberg, 1997), which these data show is governed primarily by substrate $\mathrm{pH}$ and influenced little by $\mathrm{B}$ amendment through micronutrient packages.

DTPA-extractable Fe was influenced by numerous main effects and interactions (Table 6). Substrate type was a significant effect $(P=0.0016)$, although DFB had only a marginally higher level of Fe than BPP (56 versus $52 \mathrm{mg} \cdot \mathrm{L}^{-1}$ ) averaged across all treatments. DTPA-extractable Fe decreased with increasing $\mathrm{pH}$ (Fig. 3; Table 7). Available Fe was responsive to substrate $\mathrm{pH}$, even with the addition of micronutrient fertilizer contain- ing $17 \% \mathrm{Fe}$ in the form of ferrous sulfate. Adding the micronutrient package increased available $\mathrm{Fe} \approx$ twofold over nonfertilized controls in this study. DTPA-extractable substrate $\mathrm{Fe}$ levels should range from 15 to $40 \mathrm{mg} \cdot \mathrm{L}^{-1}$ (Warncke, 1998); thus, extra available Fe from micronutrient packages may be excessive considering levels provided by DFB alone.

DTPA-extractable Mn was affected by all interactions of main effects (Table 6). The relationship between $\mathrm{Mn}$ and substrate $\mathrm{pH}$ differed for DFB and BPP substrates. DFB was best fit with a two-segment piecewise linear regression model, whereas BPP was best fit with a three-segment model (Fig. 3; Table 7). Mn from DFB increased with increasing $\mathrm{pH}$ up to 7.3 and 7.7 at 4 and 8 WAP, respectively, and declined linearly with increasing $\mathrm{pH}$ thereafter (Table 7). Mn initially decreased with increasing $\mathrm{pH}$ in BPP substrates, then increased over the range of 5.0 to 6.7 and 3.9 to 6.6 at 4 and 8 WAP, respectively, and then declined thereafter. Among all nutrients analyzed in this and other research by the authors, measuring Mn availability has been most troublesome. Handreck (1995) reviewed research on Mn extraction from potting media and summarizes the body of work as conflicting, largely as a result of the complexity of Mn chemistry in soils and substrates. Further research focusing specifically on $\mathrm{Mn}$ is required to better understand how this nutrient reacts in DFB substrates.

DTPA-extractable $\mathrm{Cu}$ responded to numerous main effects and interactions (Table 6), including substrate type, although differences between the substrates were not remarkable. DTPA-extractable $\mathrm{Cu}$ responded quadratically with increasing substrate $\mathrm{pH}$ (Fig. 3). Across the range of $\mathrm{pH}, \mathrm{Cu}$ levels ranged from 2.3 to $7.6 \mathrm{mg} \cdot \mathrm{L}^{-1}$, whereas in nonamended DFB, $\mathrm{Cu}$ decreased exponentially with increasing $\mathrm{pH}$ with levels ranging from 0.13 to $0.40 \mathrm{mg} \cdot \mathrm{L}^{-1}$ (Altland and Buamscha, 2008). Handreck (1994) reported no $\mathrm{Cu}$ response in pine bark substrates with $\mathrm{pH}$ adjusted from 4.5 to 6.5 , although the lack of observed response is his study is likely the result of the narrow range of $\mathrm{pH}$ studied. In a separate study, Handreck (1990) concluded that chrysanthemum (Chrysanthemum morifolium Ramat.) requires $0.25 \mathrm{mg} \cdot \mathrm{L}^{-1}$ of DTPA-extractable $\mathrm{Cu}$ for adequate vegetative growth but at least $5.1 \mathrm{mg} \cdot \mathrm{L}^{-1} \mathrm{Cu}$ for optimum flowering. By these standards, unamended DFB contains sufficient $\mathrm{Cu}$ for vegetative growth assuming $\mathrm{pH}$ is sufficiently low (less than 6.7) (Buamscha et al., 2007). Handreck (1990) goes on to suggest 2 or $20 \mathrm{mg} \cdot \mathrm{L}^{-1} \mathrm{Cu}$ (mass of $\mathrm{Cu}$ per volume of substrate) be amended to substrates to achieve levels necessary for optimum vegetative growth or flowering, respectively. Application of $0.9 \mathrm{~kg} \cdot \mathrm{m}^{-3}$ micronutrient package $(1 \% \mathrm{Cu})$, like done in this study, is equivalent to an application of $8.9 \mathrm{mg} \cdot \mathrm{L}^{-1} \mathrm{Cu}$ (mass of $\mathrm{Cu}$ per volume of substrate). With this application rate, $\mathrm{Cu}$ was sufficiently high for vegetative growth regardless of $\mathrm{pH}$ but 
Table 7. Regression equations for relationships between water-extractable $\mathrm{NH}_{4}{ }^{+}, \mathrm{NO}_{3}{ }^{-}, \mathrm{P}, \mathrm{SO}_{4}{ }^{2-}, \mathrm{K}, \mathrm{Ca}$, $\mathrm{Mg}$, and $\mathrm{Na}$ and substrate $\mathrm{pH}$; and DTPA-extractable $\mathrm{B}, \mathrm{Fe}, \mathrm{Mn}, \mathrm{Zn}, \mathrm{Al}$, and $\mathrm{Cu}$ and substrate $\mathrm{pH}$ (Figs. 1, 2 and 3). Multiple equations within a date and substrate represent each of the segments from piecewise linear regression.

\begin{tabular}{|c|c|c|c|c|c|}
\hline Nutrient & $\mathrm{WAP}^{\mathrm{z}}$ & Substrate $^{y}$ & $\begin{array}{r}\text { Equation }^{\mathrm{x}} \\
\end{array}$ & Range $^{w}$ & $\mathrm{r}^{2}$ \\
\hline \multirow{2}{*}{$\mathrm{NH}_{4}^{+}$} & 8 & DFB & $y=313.47 e^{-0.88 x}$ & $2.0-8.0$ & $\overline{0.87}$ \\
\hline & & BPP & $\mathrm{y}=151.11 \mathrm{e}^{-0.62 \mathrm{x}}$ & $1.9-7.9$ & 0.79 \\
\hline \multirow[t]{2}{*}{$\mathrm{NO}_{3}^{-}$} & 8 & DFB & $\mathrm{y}=92.46 \mathrm{e}^{-0.49}$ & $2.0-8.0$ & 0.77 \\
\hline & & BPP & $y=162.76 e^{-0.75 x}$ & $1.9-7.9$ & 0.83 \\
\hline \multirow[t]{4}{*}{$\mathrm{P}$} & 4 & DFB & $y=11.55-1.28 x$ & $3.4-7.9$ & 0.50 \\
\hline & & BPP & $\mathrm{y}=11.87-1.44 \mathrm{x}$ & $2.5-7.8$ & 0.71 \\
\hline & 8 & DFB & $y=107.82-57.8 x+11.35 x^{2}-0.73 x^{3}$ & $2.0-8.0$ & 0.88 \\
\hline & & BPP & $y=93.76-47.03 x+9.13 x^{2}-0.59 x^{3}$ & $1.9-7.9$ & 0.85 \\
\hline \multirow[t]{4}{*}{$\mathrm{SO}_{4}^{2-}$} & 4 & DFB & $y=2,602-849 x+69 x^{2}$ & $3.4-7.9$ & 0.79 \\
\hline & & BPP & $y=3,147-1,045 x+87 x^{2}$ & $2.5-7.8$ & 0.94 \\
\hline & 8 & DFB & $y=3,222-1,043 x+83 x^{2}$ & $2.0-8.0$ & 0.94 \\
\hline & & BPP & $y=4,875-1,628 x+134 x^{2}$ & $1.9-7.9$ & 0.87 \\
\hline \multirow[t]{4}{*}{ K } & 4 & DFB & $y=428-137 x+12 x^{2}$ & $3.4-7.9$ & 0.69 \\
\hline & & BPP & $y=221-71 x+6 x^{2}$ & $2.5-7.8$ & 0.60 \\
\hline & 8 & DFB & $y=244-68 x+6 x^{2}$ & $2.0-8.0$ & 0.59 \\
\hline & & BPP & $y=232-67 x+6 x^{2}$ & $1.9-7.9$ & 0.53 \\
\hline \multirow[t]{4}{*}{$\mathrm{Ca}$} & 4 & DFB & $y=751-276 x+25 x^{2}$ & $3.4-7.9$ & 0.82 \\
\hline & & BPP & $y=1,001-368 x+34 x^{2}$ & $2.5-7.8$ & 0.88 \\
\hline & 8 & DFB & $y=426-153 x+14 x^{2}$ & $2.0-8.0$ & 0.80 \\
\hline & & BPP & $y=768-280 x+26 x^{2}$ & $1.9-7.9$ & 0.88 \\
\hline \multirow[t]{4}{*}{$\mathrm{Mg}$} & 4 & DFB & $y=144-47 x+4 x^{2}$ & $3.4-7.9$ & 0.70 \\
\hline & & BPP & $y=124-41 x+3 x^{2}$ & $2.5-7.8$ & 0.90 \\
\hline & 8 & DFB & $y=58-17 x+x^{2}$ & $2.0-8.0$ & 0.73 \\
\hline & & BPP & $y=63-20 x+2 x^{2}$ & $1.9-7.9$ & 0.78 \\
\hline \multirow[t]{4}{*}{$\mathrm{Na}$} & 4 & DFB & $y=89-26 x+2 x^{2}$ & $3.4-7.9$ & 0.23 \\
\hline & & BPP & $y=55-14 x+x^{2}$ & $2.5-7.8$ & 0.23 \\
\hline & 8 & DFB & $y=56-13 x+x^{2}$ & $2.0-8.0$ & 0.46 \\
\hline & & BPP & $y=74-17 x+2 x^{2}$ & $1.9-7.9$ & 0.62 \\
\hline \multirow[t]{4}{*}{ B } & 4 & DFB & $y=1.07-0.13 x$ & $3.4-7.9$ & 0.71 \\
\hline & & BPP & $y=0.98-0.12 x$ & $2.5-7.8$ & 0.91 \\
\hline & 8 & DFB & $y=0.7-0.09 x$ & $2.0-8.0$ & 0.81 \\
\hline & & BPP & $y=0.57-0.06 x$ & $1.9-7.9$ & 0.72 \\
\hline \multirow[t]{6}{*}{$\mathrm{Fe}$} & 4 & DFB & $y=209.1-26.6 x$ & $3.4-7.9$ & 0.91 \\
\hline & & BPP & $y=130.3-21.7 x$ & $2.5-7.8$ & 0.97 \\
\hline & & & $y=302.8-40.1 x$ & $5.5-7.8$ & \\
\hline & 8 & DFB & $\mathrm{y}=183.8-21.8 \mathrm{x}$ & $2.0-8.0$ & 0.90 \\
\hline & & BPP & $y=98.7-6.1 x$ & $1.9-7.9$ & 0.96 \\
\hline & & & $y=282.7-36.2 x$ & $5.6-7.9$ & \\
\hline \multirow[t]{10}{*}{ Mn } & 4 & DFB & $y=-8.2+16.6 x$ & $3.4-7.9$ & 0.81 \\
\hline & & & $y=141.3-15.5 x$ & $7.3-7.9$ & \\
\hline & & BPP & $\mathrm{y}=54.8-9.3 \mathrm{x}$ & $2.5-5.0$ & 0.82 \\
\hline & & & $y=-56.7+13.1 x$ & $5.0-6.7$ & \\
\hline & & & $y=101.2-10.5 x$ & $6.7-7.8$ & \\
\hline & 8 & DFB & $y=-3.7+9.5 x$ & $2.0-7.7$ & 0.71 \\
\hline & & & $y=568.7-68.8 x$ & $7.7-8.0$ & \\
\hline & & BPP & $\mathrm{y}=15.8-2.9 x$ & $1.9-3.9$ & 0.81 \\
\hline & & & $\mathrm{y}=-35.0+10.0 x$ & $3.9-6.6$ & \\
\hline & & & $y=103.3-10.9 x$ & $6.6-7.9$ & \\
\hline \multirow[t]{4}{*}{$\mathrm{Zn}$} & 8 & DFB & $\mathrm{y}=-0.9+4.0 \mathrm{x}$ & $2.0-6.6$ & 0.66 \\
\hline & & & $y=36.4-3.6 x$ & $6.6-8.0$ & \\
\hline & & BPP & $y=-1.7+4.4 x$ & $1.9-7.0$ & 0.76 \\
\hline & & & $y=74.4-8.5 x$ & $7.0-7.9$ & \\
\hline \multirow[t]{4}{*}{$\mathrm{Al}$} & 4 & DFB & $y=51.4 e^{-0.43 x}$ & $3.4-7.9$ & 0.65 \\
\hline & & BPP & $y=660.0 e^{-1.06 x}$ & $2.5-7.8$ & 0.94 \\
\hline & 8 & DFB & $y=102.3 e^{-0.58 x}$ & $2.0-8.0$ & 0.84 \\
\hline & & BPP & $y=172.1 e^{-0.73 x}$ & $1.9-7.9$ & 0.87 \\
\hline \multirow[t]{4}{*}{$\mathrm{Cu}$} & 4 & DFB & $y=4.5+0.7 x-0.1 x^{2}$ & $3.4-7.9$ & 0.75 \\
\hline & & BPP & $y=-9.9+6.5 x-0.6 x^{2}$ & $2.5-7.8$ & 0.85 \\
\hline & 8 & DFB & $y=-0.1+2.6 x-0.3 x^{2}$ & $2.0-8.0$ & 0.68 \\
\hline & & BPP & $y=-2.0+3.5 x-0.3 x^{2}$ & $1.9-7.9$ & 0.65 \\
\hline
\end{tabular}

${ }^{\mathrm{z}} \mathrm{WAP}=$ weeks after potting, or the time allowed between potting and substrate analysis.

${ }^{y}$ Substrates were either DFB $=100 \%$ douglas fir bank, or BPP $=75$ DFB: 15 peat:10 pumice (by volume). ${ }^{\mathrm{x}}$ Equations for each nutrient, WAP, and substrate combination represent each of the linear segments identified by piecewise regression analysis.

${ }^{\mathrm{w}}$ Range refers to the range of substrate $\mathrm{pH}$ to which each linear regression equation applies.

exceeded the $5.1 \mathrm{mg} \cdot \mathrm{L}^{-1}$ benchmark (for optimal flowering) with $\mathrm{pH}$ from $\approx 4$ to 6 (Fig. 3).

DTPA-extractable $\mathrm{Zn}$ was affected by substrate type $(P<0.0001)$ and other main effects (Table 6). Extractable Zn from DFB was less than that from BPP despite BPP having similar (or slightly less) extractable $\mathrm{Zn}$ just before potting. $\mathrm{Zn}$ response to substrate $\mathrm{pH}$ was best fit with two-segment piecewise regression (Fig. 3). At 4 WAP, DTPA-extractable $\mathrm{Zn}$ did not respond to substrate $\mathrm{pH}$ in either substrate (data omitted for clarity). At 8 WAP, $\mathrm{Zn}$ increased as $\mathrm{pH}$ increased up to 6.6 and 7.0 for DFB and BPP, respectively, and then declined (Table 7). Handreck (1994) reported $\mathrm{Zn}$ did not respond to $\mathrm{pH}$ over the range of 4.5 to 6.5 in a fertilized pine ( $P$. radiata $D$. Don) bark substrate. Ogden et al. (1987) also stated liming has no effect on $\mathrm{Zn}$ availability in pine (P. taeda L.) bark substrates. Our data show $\mathrm{Zn}$ responds to $\mathrm{pH}$, but over a much wider range of $\mathrm{pH}$ than what was observed with others (Handreck, 1994; Ogden et al., 1987). Zn availability in this study might also be related to cation competition with $\mathrm{K}, \mathrm{Ca}$, and $\mathrm{Mg}$ (Fig. 2). As each of these nutrients decreased in availability, $\mathrm{Zn}$ availability increased and vice versa.

DTPA-extractable Al was affected by substrate type $(P=0.0136)$, although this difference manifested most prominently in the highest $\mathrm{S}$ amendment rate (Table 5). DTPA-extractable Al decreased exponentially with increasing $\mathrm{pH}$ (Fig. 3). A similar response to $\mathrm{pH}$ was observed in unamended DFB (Altland and Buamscha, 2008). Ogden (1982) showed that pine (Pinus taeda L.) bark ash contains high concentrations of $\mathrm{Al}$, although no symptoms of $\mathrm{Al}$ toxicity were apparent in a series of experiments with tomato (Lycopersicon esculentum Mill.). Wright (1989) reviewed Al interactions with soils and crops and described Al speciation as complex, dependent on soil $\mathrm{pH}$ and other mineralogical factors, and difficult to predict. Wright (1989) also explains that Al forms complexing ligands with sulfate and soluble organic compounds, which alleviates Al toxicity. We speculate that $\mathrm{Al}$ is present in relatively high levels ( $\mathrm{pH}$-dependent) in DFB but in nontoxic forms as a result of a consistent supply of sulfate from bark (Table 1) and fertilizer amendments as well as the presence of soluble organic compounds in DFB.

These results have several practical implications. Both $\mathrm{N}$ forms and $\mathrm{P}$ were found in higher concentrations than at low $\mathrm{pH}$. Although greater $\mathrm{NH}_{4}-\mathrm{N}$ retention was attributed to reduced nitrification rates at low $\mathrm{pH}$, retention of the anions $\mathrm{NO}_{3}{ }^{-}$and $\mathrm{P}\left(\right.$ as $\left.\mathrm{P}_{2} \mathrm{O}_{4}{ }^{-}\right)$ is likely the result of higher AEC with decreasing $\mathrm{pH}$. Nitrates and $\mathrm{P}$ are known to leach readily from substrates and often identified as the most serious threat for environmental contamination of surface waters and groundwater from container nurseries. It is possible that reduction in $\mathrm{pH}$ of substrates could lead to greater $\mathrm{N}$ and $\mathrm{P}$ retention, thus increasing $\mathrm{N}$ and $\mathrm{P}$ availability to crops and reducing their losses resulting from leaching.

The quadratic response of the cations $\mathrm{K}$, $\mathrm{Ca}, \mathrm{Mg}$, and $\mathrm{Na}$ was most surprising. In a review of root medium chemical properties, Argo (1998) concludes that low $\mathrm{pH}$ does not reduce $\mathrm{Ca}$ availability but that low $\mathrm{pH}$ was an indication of a lack of $\mathrm{Ca}$ sources applied to the media. Our results provide a little more clarity in demonstrating that reducing $\mathrm{pH}$ with acidifying amendments ( $\mathrm{S}$, for example) 
below the native $\mathrm{pH}$ of DFB results in elevated $\mathrm{Ca}$ availability. The rationale for applying lime to nursery containers is that it not only raises $\mathrm{pH}$, but also provides a source of $\mathrm{Ca}$ (and $\mathrm{Mg}$ with dolomitic lime). However, our research shows that when lower $\mathrm{pH}$ is desired, there is sufficient $\mathrm{Ca}$ available from DFB so that additional $\mathrm{Ca}$ sources are not necessary.

The micronutrients $\mathrm{B}$ and $\mathrm{Fe}$ decreased with increasing $\mathrm{pH}$, as expected. However, DTPA extractions of $\mathrm{Mn}, \mathrm{Zn}$, and $\mathrm{Cu}$ behaved unexpectedly in response to $\mathrm{pH}$ with each increasing and decreasing over the range of observed pH. Buamscha et al. (2007) showed that DTPA-extractable micronutrients are well correlated to foliar levels in annual vinca [Catharanthus roseus (L.) G. Don] but that plant Mn was better correlated to water extractions. However, the $\mathrm{pH}$ range in the referenced study (Buamscha et al., 2007) was much narrower than this study. Future research evaluating plant responses over a wide range of $\mathrm{pH}$ is necessary to more thoroughly understand how DTPA or water extractions correlate with plant availability.

The potential number of substrate combinations using DFB, peatmoss, pumice, and other substrate components is virtually limitless, thus defying a complete nutritional analysis of all substrate types. This research shows that DFB alone responds similarly to a typical combination of DFB, peatmoss, and pumice. Most nursery producers in the Pacific Northwest use substrates that are predominantly DFB (greater than 60\%) amended to some extent with peatmoss, pumice, sand, compost, and other components (personal observation). Without testing each substrate combination, results from this experiment can be used as a model of how nutrient availability in DFB substrates respond to $\mathrm{pH}$.

This research suggests that availability of most nutrients would be greater at lower $\mathrm{pH}$. Despite this, no single $\mathrm{pH}$ range is universally ideal for all crops. In peatmoss substrates, Argo and Fisher (2002) explain that prefer- ence for $\mathrm{pH}$ among bedding plants is tied primarily to species-dependent $\mathrm{Fe}$ uptake efficiency in that some plants overaccumulate $\mathrm{Fe}$ at low $\mathrm{pH}$ and thus are better suited to high $\mathrm{pH}$ substrates. Conversely, some plants are inefficient in absorbing $\mathrm{Fe}$ and other micronutrients and thus require lower $\mathrm{pH}$. More research is needed to determine optimal $\mathrm{pH}$ ranges for woody plants grown in containers and how substrate $\mathrm{pH}$ affects nutrient availability to those crops.

\section{Literature Cited}

Altland, J.E. 2006a. It's in the $\mathrm{H}_{2} \mathrm{O}$. Digger 50: $47-51$.

Altland, J.E. 2006b. Substrate pH, a tricky topic. Digger 50:42-47.

Altland, J.E. and M.G. Buamscha. 2008. Nutrient availability from Douglas fir bark in response to substrate $\mathrm{pH}$. HortScience 43:478-483.

Argo, W.R. 1998. Root medium chemical properties. HortTechnology 8:486-493.

Argo, W.R. and P.R. Fisher. 2002. Understanding $\mathrm{pH}$ management for container-grown crops. Meister Media Worldwide, Willoughby, $\mathrm{OH}$.

Bennett, S.M. and J.C. Peterson. 1989. The effect of $\mathrm{pH}$ on sulfate availability in sphagnum peat. Commun. Soil Sci. Plant Anal. 20:1769-1776.

Berghage, R.D., D.M. Krauskopf, D.D. Warncke, and I. Widders. 1987. Micronutrient testing of plant growth media: Extractant identification and evaluation. Commun. Soil Sci. Plant Anal. 18:1089-1109.

Buamscha, M.G., J.E. Altland, D.M. Sullivan, and D.A. Horneck. 2007. Micronutrient availability in fresh and aged Douglas fir bark. HortScience 42:152-156.

Enloe, H.A., R.C. Graham, and S.C. Sillett. 2006. Arboreal histosols in old-growth redwood forest canopies, northern California. Soil Sci. Soc. Amer. J. 70:408-418.

Favaretto, N., L.D. Norton, B.C. Joern, and S.M Brouder. 2006. Gypsum amendment and exchangeable calcium and magnesium affecting phosphorus and nitrogen in runoff. Soil Sci. Soc. Amer. J. 70:1788-1796.

Fisher, P., J. Huang, and W. Argo. 2006. Modeling lime reaction in peat-based substrates. Acta Hort. 718:461-468.

Gavlak, R., D. Horneck, R. Miller, and J. KotubyAmacher. 2003. Soil, plant, and water reference methods for the western region. 2nd Ed. WCC103 Publication, Fort Collins, CO.

Goldberg, S. 1997. Reactions of boron with soils. Plant Soil 193:35-48.

Handreck, K.A. 1986. Critical concentrations of sulfur in liquid feeds for plants in containers. Scientia Hort. 30:1-17.

Handreck, K.A. 1990. Extractants for assessing the availability of copper to Chrysanthemum morifolium cultivar 'Yellow Mandalay' growing in soil-less media. Scientia Hort. 44:323-334.

Handreck, K.A. 1994. Effect of pH on the uptake of cadmium, copper, and zinc from soilless media containing sewage sludge. Commun. Soil Sci. Plant Anal. 25:1913-1927.

Handreck, K.A. 1995. Forms and extractability of manganese in potting media. Commun. Soil Sci. Plant Anal. 26:317-328.

Lucas, R.E. and J.F. Davis. 1961. Relationships between $\mathrm{pH}$ values of organic soils and availabilities of 12 plant nutrients. Soil Sci. 92:171-182.

Niemiera, A.X. and R.D. Wright. 1986. Effect of liming rate on nitrification in a pine bark medium. J. Amer. Soc. Hort. Sci. 111:713715.

Ogden, R.J. 1982. Reactions of plant nutrients in a pine bark medium. Univ. of Georgia, Athens, GA. M.S. Thesis.

Ogden, R.J., F.A. Pokorny, H.A. Mills, and M.G. Dunavent. 1987. Elemental status of pine barkbased potting media. Hort. Rev. (Amer. Soc. Hort. Sci.) 9:103-131.

Peterson, J.C. 1980. Effects of $\mathrm{pH}$ upon nutrient availability in a commercial soilless root medium utilized for floral crop production. Ohio Agr. Res. Dev. Ctr. Circ. 268:16-19.

Schabenberger, O. and F.J. Pierce. 2002. Contemporary statistical models for the plant and soil sciences. CRC Press, Boca Raton, FL.

Warncke, D. 1998. Recommeded test procedure for greenhouse growth media, p. 34-37. In: Dahnke,W.C. (ed.). Recommended chemical soil test procedures for the north central region. North Central Reg. Res. Pub. No. 221. Miss. Agr. Expt. Stat. SB 1001

Wright, R.D. and L.E. Hinsley. 1991. Growth of containerized eastern redcedar amended with dolomitic limestone and micronutrients. HortScience 26:143-145.

Wright, R.J. 1989. Soil aluminum toxicity and plant growth. Commun. Soil Sci. Plant Anal. 20:1479-1497. 